\title{
CONTRIBUTION OF TOPOGRAPHY AND INCIDENT SOLAR RADIATION TO VARIATION OF SOIL AND PLANT LITTER AT AN AREA WITH HETEROGENEOUS TERRAIN
}

\author{
Felipe Cito Nettesheim( ${ }^{(1)}$, Tiago de Conto $^{(2)}$, Marcos Gervasio Pereira $^{(3)^{*}}$ and Deivid Lopes Machado $^{(4)}$ \\ (1) Universidade Federal do Rio de Janeiro, Departamento de Ecologia, Programa de Pós-graduação em Ecologia, Rio de Janeiro, \\ Rio de Janeiro, Brasil. \\ (2) Universidade de São Paulo, Escola Superior de Agricultura Luiz de Queiroz, Programa de Pós-graduação em Recursos Florestais, \\ Piracicaba, São Paulo, Brasil. \\ (3) Universidade Federal Rural do Rio de Janeiro, Departamento de Solos, Seropédica, Rio de Janeiro, Brasil. \\ (4) Universidade Estadual de São Paulo, Faculdade de Ciências Agronômicas, Programa de Pós-graduação em Ciência Florestal, \\ Botucatu, São Paulo, Brasil. \\ * Corresponding author. \\ E-mail: gervasio@ufrrj.br
}

\begin{abstract}
Natural processes that determine soil and plant litter properties are controlled by multiple factors. However, little attention has been given to distinguishing the effects of environmental factors from the effects of spatial structure of the area on the distribution of soil and litter properties in tropical ecosystems covering heterogeneous topographies. The aim of this study was to assess patterns of soil and litter variation in a tropical area that intercepts different levels of solar radiation throughout the year since its topography has slopes predominantly facing opposing geographic directions. Soil data $(\mathrm{pH}, \mathrm{C}, \mathrm{N}, \mathrm{P}, \mathrm{H}+\mathrm{Al}$, $\mathrm{Ca}, \mathrm{Mg}, \mathrm{K}, \mathrm{Al}, \mathrm{Na}$, sand, and silt) and plant litter data ( $, \mathrm{K}, \mathrm{Ca}, \mathrm{P}$, and $\mathrm{Mg}$ ) were gathered together with the geographic coordinates (to model the spatial structure) of 40 sampling units established at two sites composed of slopes predominantly facing northwest and southeast (20 units each). Soil and litter chemical properties varied more among slopes within similar geographic orientations than between the slopes facing opposing directions. Both the incident solar radiation and the spatial structure of the area were relevant in explaining the patterns detected in variation of soil and plant litter. Individual contributions of incident solar radiation to explain the variation in the properties evaluated suggested that this and other environmental factors may play a particularly relevant role in determining soil and plant litter distribution in tropical areas with heterogeneous topography. Furthermore, this
\end{abstract}


study corroborates that the spatial structure of the area also plays an important role in the distribution of soil and litter within this type of landscape, which appears to be consistent with the action of water movement mechanisms in such areas.

Keywords: tropical forest, spatial factors, environmental factors, slope geographic orientation, soil chemistry, litter chemistry.

\title{
RESUMO: CONTRIBUIÇÃO DA TOPOGRAFIA E DA INCIDÊNCIA SOLAR NA VARIAÇÃO DO SOLO E DA SERAPILHEIRA EM ÁREA COM TERRENO HETEROGENÊO
}

\begin{abstract}
Os processos naturais que determinam os atributos do solo e da serapilheira são controlados por diversos fatores. Entretanto, pouca atenção tem sido dada para diferenciar o efeito de fatores ambientais de efeitos da estrutura espacial da área sobre a distribuição de atributos do solo e da serapilheira em ecossistemas tropicais em topografias heterogêneas. O objetivo deste estudo foi avaliar padrões de variação dos atributos químicos do solo e da serapilheira em uma área tropical que intercepta níveis distintos de incidência solar ao longo do ano, dado que sua topografia possui encostas predominantemente voltadas para direções geográficas opostas. Dados de solo ( $\mathrm{pH}, \mathrm{C}, \mathrm{N}, \mathrm{P}, \mathrm{H}+\mathrm{Al}, \mathrm{Ca}, \mathrm{Mg}, \mathrm{K}, \mathrm{Al}, \mathrm{Na}$, areia e silte) e serapilheira ( $N, K, C a, P$ e $\mathrm{Mg}$ ) foram coletados junto às coordenadas geográficas (para modelar a estrutura espacial) de 40 unidades amostrais estabelecidas em dois sitios compostos, respectivamente, de encostas voltadas para noroeste e sudeste (20 unidades em cada). Os atributos do solo e da serapilheira variaram mais entre encostas voltadas para orientações geográficas semelhantes do que entre encostas voltadas para orientações opostas. Tanto a incidência solar quanto a estrutura espacial da área foram relevantes para explicar os padrões detectados de variação do solo e da serapilheira. As contribuições individuais da incidência solar para explicar a variação dos atributos avaliados sugerem que esse e outros fatores ambientais podem ter papel particularmente relevante na determinação da distribuição do solo e da serapilheira em áreas tropicais com topografia heterogênea. Este estudo corrobora ainda que a estrutura espacial da área também tem papel importante na distribuição do solo e da serapilheira neste tipo de paisagem, o que parece consistente com a ação de mecanismos relacionados à movimentação da água nesses locais.
\end{abstract}

Palavras-chave: floresta tropical, fatores espaciais, fatores ambientais, orientação geográfica da encosta, química dos solos, química da serapilheira.

\section{INTRODUCTION}

Tropical forests are one of the richest and most complex natural systems on the planet (Brummit and Nic Lughadha, 2003; Leigh et al., 2004). Their great richness of species has repeatedly been linked to accelerated dynamics of natural processes and high availability of natural resources (Pinto et al., 2006; Homeier et al., 2010; Putten et al., 2013). A frequent approach is to use the relationships between plants and soil to evaluate the variation in richness of tropical forests, operating under the assumption that soil is a main plant resource (Chen et al., 1997; Oliveira-Filho et al., 2001; Budke et al., 2007; John et al., 2007; Gleason et al., 2010; Laurance et al., 2010; Aponte et al., 2013; Brandt et al., 2013). As such, evaluating the soil independently of plants is important to shed light on the particular processes that drive its variation and may, consequently, determine vegetation distribution in tropical forests.

Soil is formed as consequence of the combination of parent material, climate, organisms, topography, and time (Jenny, 1941; Fanning and Fanning, 1989). Once formed, its dynamics are closely related to the plant litter component (Troeh and Thompson, 2005). Litter is made up of dead plant parts deposited on the soil and represents a stock that gradually releases nutrients to reintegrate soil chemistry (Fassbender, 1993). Thus, it is common that the same factors that affect the soil also affect the litter component. Environmental factors that vary due to topographic changes may play a particularly important role in determining the variation in both soil and litter in landscapes with heterogeneous terrains (Chen et al., 1997; Seibert et al., 2007). Environmental factors are often studied in an isolated manner to avoid confounding trends and to allow a better understanding of their effects on the soil and the litter (Sariyildiz and Küçük, 2008; Alvarez-Clare and Mack, 2011; Leff et al., 2012). This approach may provide further insight regarding how natural processes can contribute to structure plant resource distribution in tropical forests across heterogeneous terrains.

As stated above, topography can play a decisive role in the dynamics and structuring of soil and litter. Topographic features like altitude, slope, and surface curvature can affect soil and litter by modulating changes in environmental factors, 
above and below ground water routes, sediment deposition, and processes such as percolation and lixiviation (Huggett, 2007). These features change within shorter distances when the terrain becomes more heterogeneous, as is commonly observed in tropical regions with mountainous terrain (Budke et al., 2007; Unger et al., 2012). This implies that areas with rougher topographies will probably have a greater contribution from the spatial structure in explaining soil and litter variation patterns. However, changes in topographic features also determine the variation in environmental factors that are likely to have a share of importance in explaining soil and litter variation patterns; thus these environmental factors are themselves spatially structured. Separating the effects of spatial structures from the effects caused by environmental factors within this framework may lead to better landscape management decisions regarding tropical regions with heterogeneous topography.

An environmental factor that varies across heterogeneous topographies and may particularly have an impact on soil and litter dynamics is incident solar radiation. The amount of incident solar radiation can alter air and soil temperature and moisture (van de Berg and Santos, 2003; Aguilar et al., 2010; Gao et al., 2011). This determines the ionic composition of the soil solution by affecting litter and soil nutrient release rates (García et al., 2006). The sunlight regime also causes variation in the metabolism of microorganisms that control nutrient cycling by imposing different litter decomposition and mineralization rates (Austin and Vivanco, 2006). Incident solar radiation in a given area is largely determined by terrain topography. Slopes with geographic orientation predominantly facing the equator receive greater amounts of sunlight than those facing opposite directions (Dubayah, 1994; Aguilar et al., 2010). Changes in slope geographic orientation within small distances are common in heterogeneous terrains in tropical regions and create distinct incident solar radiation rates over the soil and litter. Variation in incident solar radiation is thus expected to have a spatial structure of its own, particularly in heterogeneous topographies. The distinction between the effects of incident solar radiation itself, apart from the effects of spatial structure, is important to better understand the causes of soil and litter variation patterns in heterogeneous terrains.

This effort assumes that changes in topography accompanied by incident solar radiation variation have relevant effects on soil and litter variation patterns in mountainous landscapes, due to the heterogeneous terrain of such areas. The validity of this hypothesis was evaluated by testing if patterns of variation of soil and litter chemical properties can be detected in a tropical heterogeneous topography with slopes predominantly facing opposite geographic directions and by distinguishing the relative contribution of incident solar radiation and the spatial structure to explain the patterns of variation in soil and litter chemical properties.

\section{MATERIAL AND METHODS}

\section{Area of study}

Marambaia Island is located in the southern region of the State of Rio de Janeiro, Brazil (23 4' 37.09" S; $43^{\circ} 59^{\prime} 2.15^{\prime \prime} \mathrm{W}$ ). The area is within the Atlantic Rain Forest domain, and vegetation cover is characterized as Dense Ombrophilous Submontane Forest (Veloso et al., 1991). Mean annual rainfall is $1,237.7 \mathrm{~mm}$ and mean temperature is $20.9^{\circ} \mathrm{C}$ in the winter and $26.9^{\circ} \mathrm{C}$ in the summer (Mattos, 2005). Marambaia Island consists of a homogeneous crystalline gneiss basement and altitude ranges from 0 to $641 \mathrm{~m}$. Its topography is marked by a main mountain ridge that separates slopes predominantly facing northwest from slopes predominantly turned toward the southeast (Figure 1). The geological origin of Marambaia Island is associated with the evolution of the "Serra do Mar" mountain chain. It can be traced back to the rupture of the ancient Gondwana super continent and tectonic activity from the Jurassic period (Almeida and Carneiro, 1998). Marambaia Island was completely isolated from the mainland due to a rising sea level by the end of the Quaternary period (Menezes et al., 2005; Souza et al., 2005). No severe anthropic impacts have taken place in the area since the 1970's. Past interventions were mostly restricted to the lower elevations of the slopes throughout the island (Pereira et al., 1990; Silva, 2005).

\section{Data sampling}

Two sampling sites were defined according to our objectives and the topography of the study area (Figure 1 - lower right corner). Site A consisted of slopes predominantly facing northwest, and site B consisted of slopes predominantly facing southeast. Site A is mainly characterized by greater exposure to incident solar radiation throughout the year and not receiving direct wind gusts that come from the open sea because it faces the calm waters of Sepetiba Bay. On the other hand, site B is mainly characterized by lower exposure to incident solar radiation while directly receiving continuous winds that blow from the open sea. The difference in incident solar radiation received by these two sites can also be observed in the image in the lower right corner of figure 1 , where darker areas represent less exposure to sunlight.

Twenty transects (sampling units - U) with dimensions of $50 \times 2 \mathrm{~m}$ were arbitrarily set up for sampling at site $\mathrm{A}$ and another 20 at site 


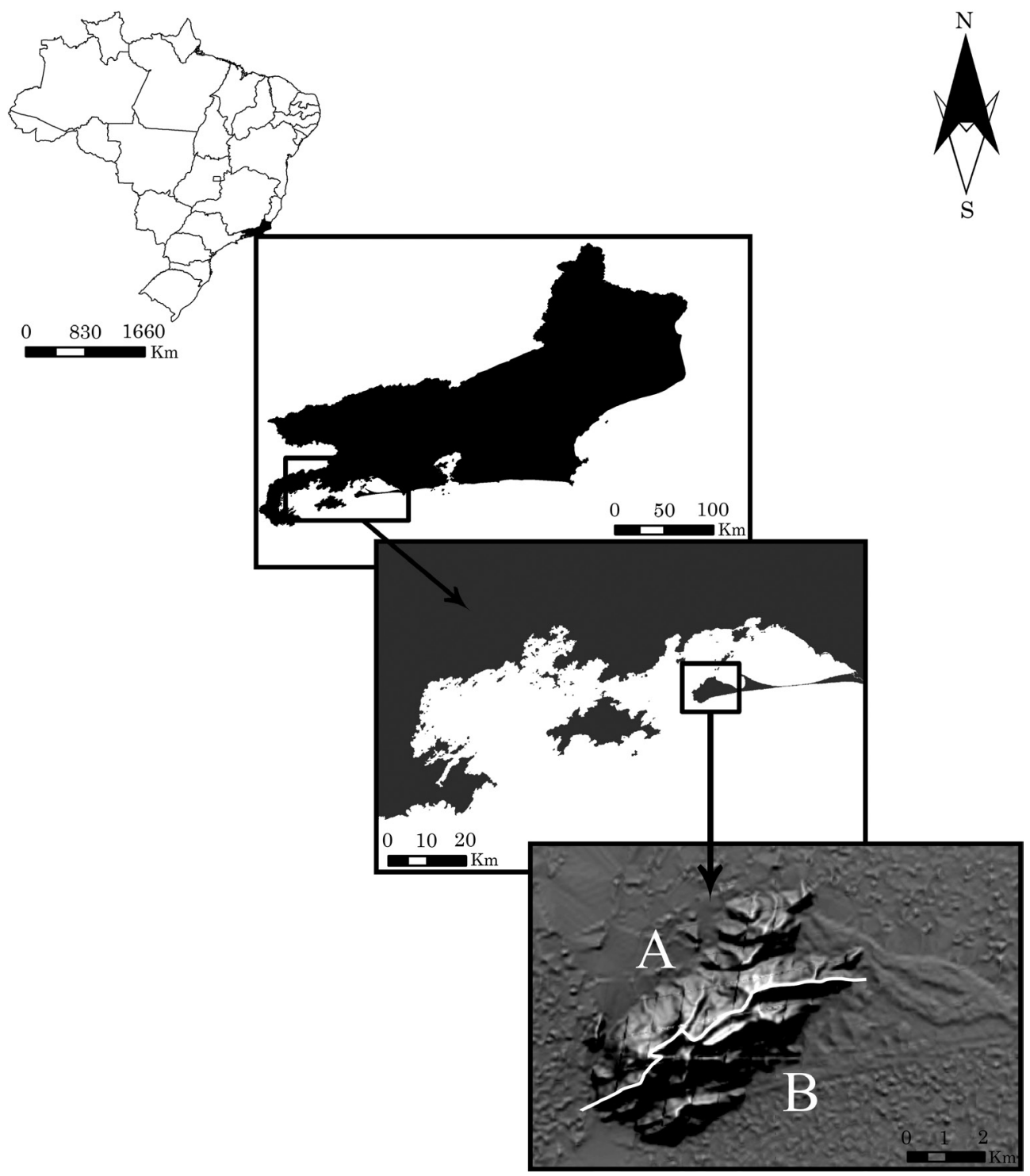

Figure 1. Location of Marambaia Island in the southern region of the state of Rio de Janeiro. Sampling sites $A$ and $B$ are distinguished in the lower right corner image by a white line drawn across the higher topographical ridge of the area. This image also indicates overall differences of incident solar radiation, where darker areas intercept less sunlight.

B (a total 40 sampling units represented the whole Marambaia Island). Four soil samples and four litter samples were collected at each of these sampling units. Each soil sample and litter sample resulted from mixing together the material collected from the middle and extremities of the sampling unit. This mixing was done because the sampling units were long and likely to encompass some variation in soil and litter chemical nutrient content. Therefore, 80 soil and litter observations were made at each site and 160 observations for the whole Marambaia Island. Soil and litter were sampled in April 2009. Litter was manually withdrawn from the ground until surface soil appeared, and the top $20 \mathrm{~cm}$ of the soil was subsequently sampled with a screw auger. Chemical analyses were conducted separately for each replication. A mean value was obtained for each plot based on the four replications, which was subsequently used in the analyses. Soil and litter samples were prepared for chemical analyses as recommended by Tedesco et al. (1995) and Embrapa (1997). The sampling procedure allowed quantification of the following items for each of the 40 plots: litter chemical data regarding total concentration of nitrogen $\left(\mathrm{N}_{\text {litter }}\right)$, potassium $\left(\mathrm{K}_{\text {litter }}\right)$, calcium $\left(\mathrm{Ca}_{\text {litter }}\right)$, phosphorus $\left(\mathrm{P}_{\text {litter }}\right)$, and magnesium $\left(\mathrm{Mg}_{\text {litter }}\right)$; and soil chemical 
data regarding $\mathrm{pH}$ in water $\left[\mathrm{pH}\left(\mathrm{H}_{2} \mathrm{O}\right)_{\text {soil }}\right]$, total concentration of organic carbon $\left(\mathrm{C}_{\text {soil }}\right)$ and nitrogen $\left(\mathrm{N}_{\text {soil }}\right)$, available phosphorus in Mehlich-1 extractor $\left(\mathrm{P}_{\text {soil }}\right)$, potential acidity in $\mathrm{Ca}(\mathrm{OAc})_{2}$ pH 7,0 $\left(\mathrm{H}+\mathrm{Al}_{\text {soil }}\right)$, calcium $\left(\mathrm{Ca}_{\text {soil }}\right)$, magnesium $\left(\mathrm{Mg}_{\text {soil }}\right)$ and aluminum $\left(\mathrm{Al}_{\text {soil }}\right)$ exchangeable in $\mathrm{KCl} 1 \mathrm{~mol} \mathrm{~L}^{-1}$, potassium $\left(\mathrm{K}_{\text {soil }}\right)$ and sodium $\left(\mathrm{Na}_{\text {soil }}\right)$ exchangeables in Mehlich-1 extractor. The relative fractions of sand $\left(\mathrm{snd}_{\text {soil }}\right)$ and silt $\left(\mathrm{slt}_{\mathrm{soil}}\right)$ present in the soil were also quantified for each plot (Embrapa, 1997).

The exact location of individual plots was recorded with a GPSMAP Garmin ${ }^{\circledR} 76 \mathrm{CSx}$ and consisted of UTM geographical coordinates ( $\mathrm{x}$ and $\mathrm{y}$ ) for the center of all 40 plots. Coordinates were then used to model the geographic space (Fortin and Dale, 2005) where the plots occur by synthesizing spatial filters (factors) with a Spatial Eigenvector Mapping procedure (SEVM) built into the Spatial Analysis in Macroecology (SAM) software (Rangel et al., 2010). These filters were assumed to respond for the spatial structure constraints caused by topography.

Data regarding mean annual incident solar radiation was obtained for each plot through GIS modeling and no in situ light measure of any kind was made. The location of each plot was overlaid on a Digital Elevation Model (DEM) of the area. The DEM was obtained using a refined image for Brazilian territory based on the SRTM (shuttle radar topography mission). The image had 1 arc second $(\sim 30 \mathrm{~m})$ of spatial resolution (Valeriano, 2008).

\section{Data analysis}

Soil and litter data were fed into a main data matrix in order to start analysis. Data in this matrix was normalized and used to run a correlation Principal Component Analysis (PCA). The broken-stick criterion indicated interpretation should focus on the first and second axes because they represented most data variation (Legendre and Legendre, 1998). Scores of each plot on the first two PCA axes were isolated as response variables PC1 and $\mathrm{PC} 2$, respectively. A Student t test was used to determine if the ordination of the plots from site $\mathrm{A}$ was different from that of site B in PC1 and in PC2 (Gotelli and Ellison, 2004).

Incident solar radiation and space (spatial filters) were related to $\mathrm{PC} 1$ and then to PC2 with regression and partial regression analyses in order to quantify their contribution in explaining the soil and litter variation contained in each of these axes (Fortin and Dale, 2005; Rangel et al., 2010). Incident solar radiation and space (spatial filters) were also related to each separate soil and litter property with regressions to determine how much of their variation could be explained by each of these two explanatory factors. Final models were obtained by keeping the spatial filters, which minimized the
Akaike Information Criterion (AIC) and increased the homogeneity of residual distribution (Zuur et al., 2007, 2009).

The effect of the treatment on soil and litter property variation did not go unnoticed. Evaluations initially took treatments into consideration in order to determine their contribution in explaining the patterns of soil and litter variation. However, the analyses revealed that the treatment effect was either negligible or redundant with incident solar radiation and the spatial filters. That is why we did not consider a treatment variable and we continued evaluating data using only incident solar radiation and spatial filters as explanatory factors.

Principal Component Analysis, broken-stick criterion and Student $\mathrm{T}$ tests were performed in the $\mathrm{R}$ programming environment v. 2.12.2 (R Development Core Team, 2014) through use of functions present in its basic interface and in the Vegan package (Oksanen et al., 2014). Regression and Partial Regression Analysis were performed with aid of the SAM software (Rangel et al., 2010).

\section{RESULTS}

Mean and standard deviation values for soil and litter properties in each sampling unit are shown in tables 1,2 , and 3 . Such information was successfully synthesized by the PCA procedure and enabled a straightforward interpretation of the soil and litter variation patterns (Figure 2 and Table 4). PC1 and PC2 together captured $63.3 \%$ of soil and litter data variation. The first component alone responsible for $46.8 \%$ of this variation and the second was responsible for an additional $16.5 \%$. Final ordination of sampling units on the first two components indicates that soil and litter properties differ between sites A and B (Figure 2).

The differentiation pattern was not detected for the ordination of sampling units on PC1 $(\mathrm{t}=-0.49$; $\mathrm{GL}=37.98 ; \mathrm{p}=0.63)$. However, PC1 captured variation of the properties $\mathrm{pH}_{\text {soil }}, \mathrm{Na}_{\text {soil }}, \mathrm{P}_{\text {soil }}, \mathrm{Al}_{\text {soil }}$, $\mathrm{C}_{\text {soil }}$, slt soil $_{\text {, }}$ snd soil $_{1}, \mathrm{P}_{\text {litter }}, \mathrm{K}_{\text {litter }}, \mathrm{N}_{\text {litter }}$, and $\mathrm{Ca}_{\text {litter }}$, and indicates that these properties vary mostly within sites A or B but not much between them (Figure 2 and Table 4). Distinction between ordination of sampling units from sites A and B was detected for PC2 ( $\mathrm{t}=6.72 ; \mathrm{GL}=37.95 ; \mathrm{p}<0.001)$, which mainly captured variation of the properties $\mathrm{K}_{\text {soil }}, \mathrm{Ca}_{\text {soil, }}$, $\mathrm{Mg}_{\text {soil }}, \mathrm{N}_{\text {soil }}, \mathrm{H}+\mathrm{Al}_{\text {soil }}$, and $\mathrm{Mg}_{\text {litter. }}$ This indicates that the variation of this second group of properties occurs mostly between sites A and B. This PCA further shows that among these properties, $\mathrm{H}+\mathrm{Al}_{\text {soil }}$, $\mathrm{N}_{\text {soil }}$, and $\mathrm{Mg}_{\text {litter }}$ tend to be higher at site $\mathrm{A}$, while $\mathrm{Ca}_{\text {soil }}, \mathrm{Mg}_{\text {soil }}$, and $\mathrm{K}_{\text {soil }}$ tend to be higher at site $\mathrm{B}$ (Figure 2 and Table 4). 


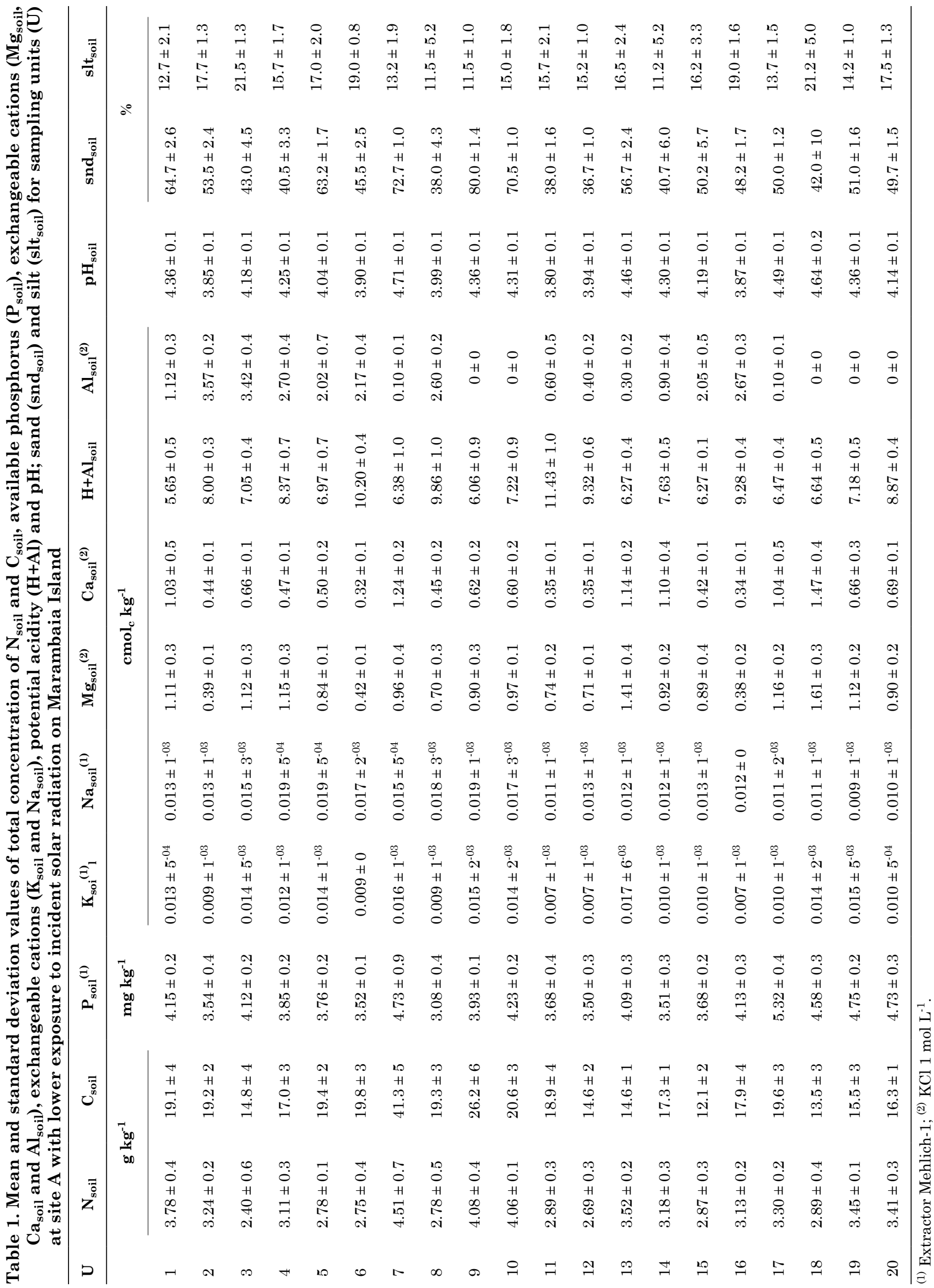




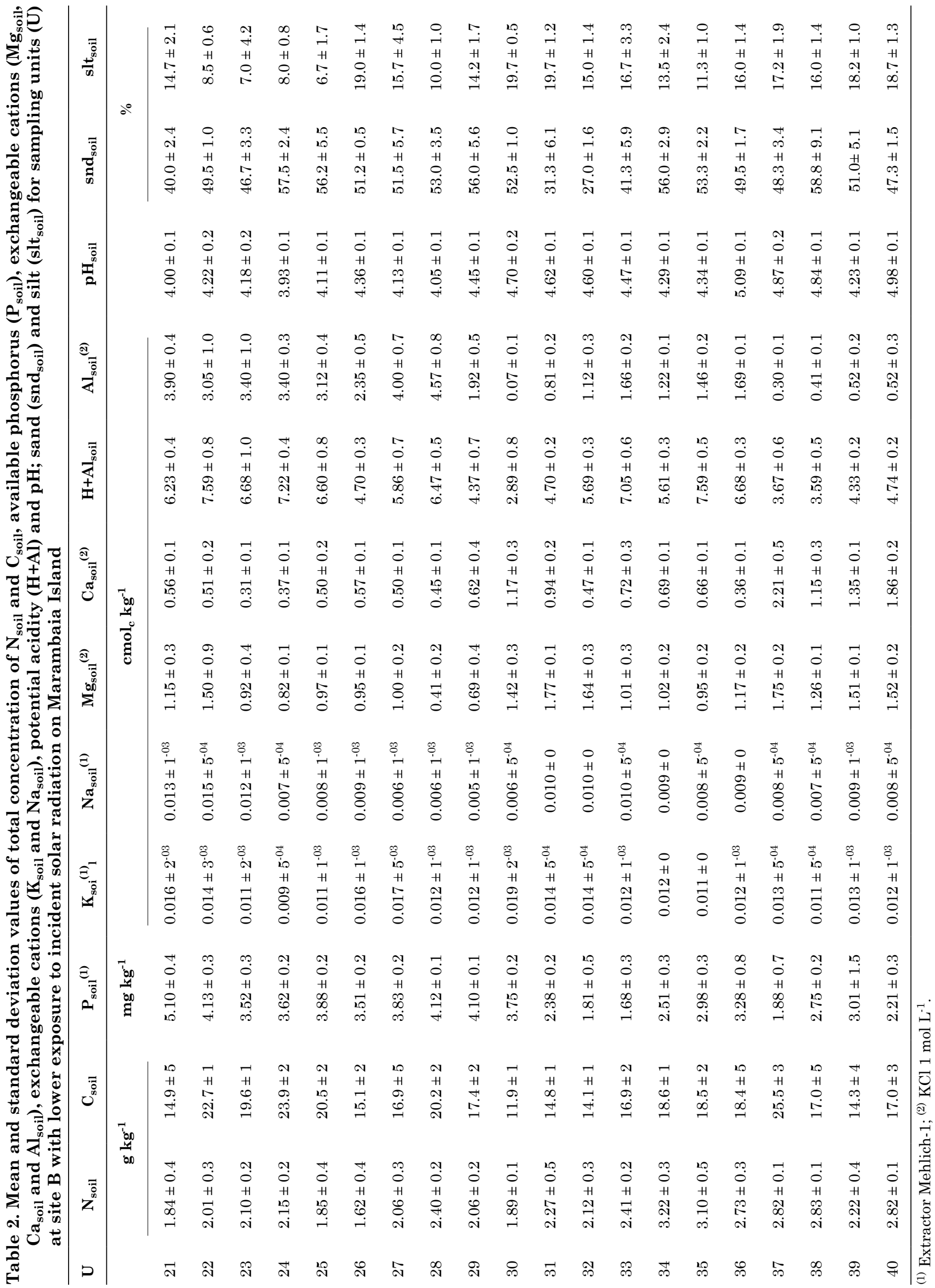


Table 3. Mean and standard deviation for litter concentration of the $\mathrm{P}, \mathrm{K}, \mathrm{N}, \mathrm{Ca}$, and $\mathrm{Mg}$ for each sampling unit (U) at sites $A$ and $B$ with greater and lower exposure to incident solar radiation, respectively, on Marambaia Island

\begin{tabular}{|c|c|c|c|c|c|}
\hline \multirow{2}{*}{$\mathbf{U}$} & \multicolumn{5}{|c|}{ Site A } \\
\hline & $\mathbf{P}_{\text {litter }}$ & $\mathbf{K}_{\text {litter }}$ & $\mathrm{N}_{\text {litter }}$ & $\mathbf{C a}_{\text {litter }}$ & $\mathbf{M g}_{\text {litter }}$ \\
\hline & \multicolumn{5}{|c|}{$\mathrm{g} \mathrm{kg}^{-1}$} \\
\hline 1 & $1.22 \pm 0.11$ & $0.43 \pm 0.05$ & $38.9 \pm 5.1$ & $70.35 \pm 3.0$ & $6.3 \pm 1.7$ \\
\hline 2 & $0.99 \pm 0.09$ & $0.36 \pm 0$ & $28.9 \pm 1.2$ & $22.4 \pm 3.8$ & $4.9 \pm 1.1$ \\
\hline 3 & $1.06 \pm 0.19$ & $0.40 \pm 0.05$ & $38.2 \pm 2.4$ & $43.4 \pm 6.9$ & $5.4 \pm 1.2$ \\
\hline 4 & $1.06 \pm 0.03$ & $0.34 \pm 0.03$ & $33.6 \pm 2.3$ & $33.9 \pm 4.4$ & $5.5 \pm 1.1$ \\
\hline 5 & $1.04 \pm 0.04$ & $0.40 \pm 0.05$ & $36.2 \pm 5.7$ & $41.0 \pm 10$ & $4.4 \pm 0.8$ \\
\hline 6 & $1.13 \pm 0.20$ & $0.35 \pm 0.02$ & $31.7 \pm 5.1$ & $24.1 \pm 10$ & $4.9 \pm 1.0$ \\
\hline 7 & $1.00 \pm 0.07$ & $0.38 \pm 0.02$ & $32.8 \pm 1.9$ & $38.3 \pm 3.2$ & $5.3 \pm 0.6$ \\
\hline 8 & $0.91 \pm 0.07$ & $0.36 \pm 0$ & $29.4 \pm 3.1$ & $23.2 \pm 5.0$ & $4.3 \pm 1.6$ \\
\hline 9 & $0.98 \pm 0.08$ & $0.40 \pm 0.02$ & $28.3 \pm 4.4$ & $34.4 \pm 6.2$ & $4.7 \pm 0.7$ \\
\hline 10 & $1.12 \pm 0.07$ & $0.40 \pm 0.05$ & $40.0 \pm 6.3$ & $53.3 \pm 3.4$ & $7.4 \pm 1.3$ \\
\hline 11 & $1.08 \pm 0.06$ & $0.38 \pm 0.02$ & $29.7 \pm 2.7$ & $16.2 \pm 7.7$ & $3.9 \pm 1.1$ \\
\hline 12 & $1.05 \pm 0.26$ & $0.33 \pm 0.07$ & $34.7 \pm 2.3$ & $25.2 \pm 5.8$ & $4.9 \pm 1.5$ \\
\hline 13 & $1.39 \pm 0.07$ & $0.36 \pm 0.09$ & $41.6 \pm 1.0$ & $66.7 \pm 13$ & $7.0 \pm 0.5$ \\
\hline 14 & $1.18 \pm 0.10$ & $0.38 \pm 0.02$ & $35.1 \pm 4.4$ & $49.0 \pm 11.2$ & $5.3 \pm 0.8$ \\
\hline 15 & $1.09 \pm 0.08$ & $0.36 \pm 0$ & $34.1 \pm 3.5$ & $27.1 \pm 6.2$ & $5.8 \pm 1.9$ \\
\hline 16 & $1.24 \pm 0.38$ & $0.36 \pm 0$ & $28.1 \pm 4.7$ & $21.1 \pm 7.5$ & $4.6 \pm 1.3$ \\
\hline 17 & $1.23 \pm 0.09$ & $0.33 \pm 0.02$ & $31 \pm 5$ & $67.5 \pm 18$ & $4.4 \pm 1.2$ \\
\hline 18 & $1.10 \pm 0.09$ & $0.36 \pm 0.06$ & $27 \pm 7.7$ & $37.9 \pm 8.4$ & $3.7 \pm 0.7$ \\
\hline 19 & $1.20 \pm 0.23$ & $0.41 \pm 0$ & $32.4 \pm 8.7$ & $46.4 \pm 9.4$ & $7.5 \pm 1.3$ \\
\hline \multirow[t]{2}{*}{20} & $1.40 \pm 0.08$ & $0.39 \pm 0.03$ & $41.1 \pm 1.4$ & $46.5 \pm 6.5$ & $7.4 \pm 0.7$ \\
\hline & & & Site B & & \\
\hline 21 & $1.15 \pm 0.25$ & $0.33 \pm 0.05$ & $27.4 \pm 2.9$ & $24.9 \pm 5.6$ & $3.1 \pm 1.2$ \\
\hline 22 & $1.09 \pm 0.20$ & $0.33 \pm 0$ & $28.6 \pm 6.0$ & $18.8 \pm 3.8$ & $3.1 \pm 1.6$ \\
\hline 23 & $1.05 \pm 0.07$ & $0.32 \pm 0.05$ & $27.3 \pm 2.8$ & $18.2 \pm 2.9$ & $3.4 \pm 1.2$ \\
\hline 24 & $0.93 \pm 0.21$ & $0.32 \pm 0.03$ & $27.8 \pm 2.6$ & $22.1 \pm 6.6$ & $3.3 \pm 0.9$ \\
\hline 25 & $1.41 \pm 0.07$ & $0.36 \pm 0.05$ & $29.3 \pm 1.4$ & $29.4 \pm 2.9$ & $4.5 \pm 1.0$ \\
\hline 26 & $0.91 \pm 0.07$ & $0.36 \pm 0.02$ & $29.8 \pm 2.0$ & $20.3 \pm 2.4$ & $3.4 \pm 1.1$ \\
\hline 27 & $1.13 \pm 0.07$ & $0.40 \pm 0.02$ & $33.2 \pm 6.8$ & $20.2 \pm 4.0$ & $3.9 \pm 1.6$ \\
\hline 28 & $1.00 \pm 0.36$ & $0.38 \pm 0$ & $29.2 \pm 3.3$ & $15.5 \pm 1.9$ & $4.4 \pm 0.5$ \\
\hline 29 & $1.10 \pm 0.19$ & $0.36 \pm 0.02$ & $34.3 \pm 2.4$ & $37.1 \pm 3.2$ & $5.7 \pm 0.9$ \\
\hline 30 & $1.24 \pm 0.05$ & $0.46 \pm 0.05$ & $35.1 \pm 3.8$ & $44.4 \pm 5.4$ & $4.6 \pm 1.4$ \\
\hline 31 & $1.42 \pm 0.14$ & $0.46 \pm 0.02$ & $40.9 \pm 3.3$ & $50.5 \pm 6.8$ & $4.5 \pm 1.5$ \\
\hline 32 & $1.12 \pm 0.10$ & $0.39 \pm 0.07$ & $29.9 \pm 6.4$ & $32.5 \pm 6.3$ & $3.6 \pm 1.7$ \\
\hline 33 & $1.07 \pm 0.11$ & $0.36 \pm 0.09$ & $31.2 \pm 3.5$ & $45.5 \pm 9.3$ & $5.7 \pm 2.1$ \\
\hline 34 & $1.05 \pm 0.10$ & $0.43 \pm 0.02$ & $30.3 \pm 1.2$ & $35.3 \pm 5.1$ & $4.4 \pm 1.0$ \\
\hline 35 & $0.99 \pm 0.20$ & $0.34 \pm 0$ & $29.6 \pm 4.4$ & $41.7 \pm 4.7$ & $5.2 \pm 1.0$ \\
\hline 36 & $1.01 \pm 0.05$ & $0.36 \pm 0$ & $33.1 \pm 1.1$ & $36.4 \pm 3.9$ & $4.4 \pm 0.2$ \\
\hline 37 & $1.19 \pm 0.09$ & $0.45 \pm 0.02$ & $37.5 \pm 5.6$ & $55.2 \pm 6.8$ & $6.2 \pm 2,0$ \\
\hline 38 & $1.16 \pm 0.07$ & $0.44 \pm 0.06$ & $35.6 \pm 7.3$ & $56.4 \pm 12$ & $7.9 \pm 2.3$ \\
\hline 39 & $1.18 \pm 0.05$ & $0.40 \pm 0$ & $33.8 \pm 6.4$ & $42.7 \pm 6.6$ & $6.9 \pm 1.2$ \\
\hline 40 & $1.18 \pm 0.08$ & $0.40 \pm 0.03$ & $32.2 \pm 5.4$ & $43.1 \pm 7.3$ & $5.1 \pm 1.8$ \\
\hline
\end{tabular}




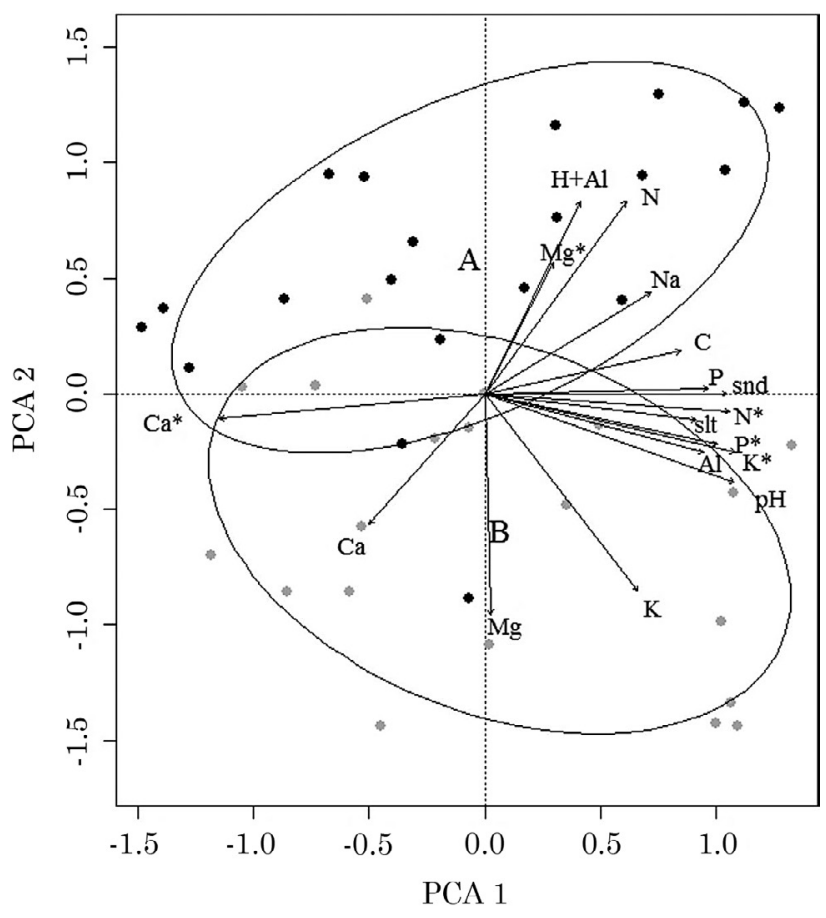

Figure 2. Final PCA configuration showing sampling units and descriptors in the reduced space of the first two components. Sampling units of sites $A$ and $B$ are represented by black and gray dots, respectively. The ellipses indicated by capital letters $A$ and $B$ further show the differentiation between the two areas. Litter properties are identified by an asterisk (*).

Models with incident solar radiation and the spatial structure successfully explained soil and litter variation synthesized by the first $\left(R_{a}^{2}=24.8\right.$; $\mathrm{F}=6.7 ; \mathrm{p}=0.003)$ and second $\left(R_{a}^{2}=49.9 ; \mathrm{F}=19.4\right.$; $\mathrm{p}<0.001)$ PCA components (Table 5). Each of these two explanatory factors made a similar contribution in explaining soil and litter variation within each site captured in the first PCA component when their effects were evaluated independently in the models. However, the independent contribution of solar incidence was almost four times greater in relation to the independent contribution of spatial structure in explaining variation of soil and litter properties between sites captured by the second PCA component (Table 5). Shared contribution of these fractions was small for both PCA components.

Models with incident solar radiation and the spatial structure also successfully explained at least part of the variation of the 15 soil and litter properties evaluated (no fit detected for slt soil $_{\text {and }}$ and $\mathrm{Mg}_{\text {litter }}$ ) when considered individually as response variables. Overall fits of the models for each property explained up to $58 \%$ of their total variation, whereas most explained between $13 \%$ and $33 \%$. Best fits for the models were obtained for $\mathrm{P}_{\text {soil }}, \mathrm{K}_{\text {soil }}$, and $\mathrm{snd}_{\text {soil }}$,
Table 4. Correlation values between the soil and litter properties and each of the first two components $\left(\mathrm{PC}_{\mathrm{i}}\right)$ of the Principal Component Analysis

\begin{tabular}{lcc}
\hline & PC 1 & PC 2 \\
\hline $\mathrm{pH}_{\text {soil }}$ & 0.87 & -0.31 \\
$\mathrm{~K}_{\text {soil }}$ & 0.54 & -0.69 \\
$\mathrm{Na}_{\text {soil }}$ & 0.58 & 0.36 \\
$\mathrm{P}_{\text {soil }}$ & 0.78 & 0.02 \\
$\mathrm{Ca}_{\text {soil }}$ & -0.40 & -0.46 \\
$\mathrm{Mg}_{\text {soil }}$ & 0.02 & -0.78 \\
$\mathrm{Al}_{\text {soil }}$ & 0.77 & -0.21 \\
$\mathrm{C}_{\text {soil }}$ & 0.68 & 0.15 \\
$\mathrm{~N}_{\text {soil }}$ & 0.49 & 0.67 \\
$\mathrm{H}+\mathrm{Al}_{\text {soil }}$ & 0.33 & 0.67 \\
$\mathrm{Slt}_{\text {soil }}$ & 0.85 & 0.001 \\
$\mathrm{Snd}_{\text {soil }}$ & 0.74 & -0.09 \\
$\mathrm{P}_{\text {litter }}$ & 0.81 & -0.18 \\
$\mathrm{~K}_{\text {litter }}$ & 0.87 & -0.21 \\
$\mathrm{~N}_{\text {litter }}$ & 0.86 & -0.06 \\
$\mathrm{Ca}_{\text {litter }}$ & -0.93 & -0.09 \\
$\mathrm{Mg}_{\text {litter }}$ & 0.24 & 0.46 \\
\hline
\end{tabular}

and the worst fits were found for $\mathrm{Ca}_{\text {soil }}, \mathrm{C}_{\text {soil }}, \mathrm{K}_{\text {litter, }}$, and $\mathrm{N}_{\text {litter }}$ (Table 5).

Controlling for the effects of the spatial structure, the experiment showed that incident solar radiation plays a relevant independent role in the variation of almost all (with exception of $\mathrm{Ca}_{\text {soil }}$ ) of the soil and litter properties considered. Incident solar radiation plays a greater role than the spatial structure in 11 of the 17 soil and litter properties evaluated. Its greater relative importance in explaining the variation in these 11 properties varied from 1.1 to 31.4 times the importance of the spatial structure. Incident solar radiation was more important in explaining the variation of three $\left(\mathrm{K}_{\mathrm{soil}}, \mathrm{N}_{\text {soil }}\right.$, and $\mathrm{H}+\mathrm{Al}_{\text {soil }}$ ) of the six properties found to vary mostly between sites and eight $\left(\mathrm{pH}_{\text {soil }}, \mathrm{Al}_{\text {soil }}, \mathrm{C}_{\text {soil }}\right.$, snd $\mathrm{soil}_{\text {sil }}$, $\mathrm{P}_{\text {litter }}, \mathrm{K}_{\text {litter }}, \mathrm{N}_{\text {litter }}$ and $\mathrm{Ca}_{\text {litter }}$ ) of the 11 properties that varied mostly within each site (Table 5).

In contrast, controlling for the effects of incident solar radiation, the experiment indicated that the spatial structure alone was important in more than half of the fitted models (including for both PCA components). The spatial structure separately played a particularly relevant role in explaining eight of the 17 soil and litter properties evaluated and had a greater relative importance in four of those cases $\left(\mathrm{Na}_{\text {soil }}, \mathrm{P}_{\text {soil }}, \mathrm{Ca}_{\text {soil }}\right.$, and $\left.\mathrm{Mg}_{\text {soil }}\right)$. This greater importance varied from 1.1 to 6.5 times the importance of incident solar radiation. The spatial structure played a greater role in explaining the variation of two $\left(\mathrm{Ca}_{\text {soil }}\right.$ and $\mathrm{Mg}_{\text {soil }}$ ) of the six properties found to vary mostly between sites, and two $\left(\mathrm{Na}_{\text {soil }}\right.$ and $\left.\mathrm{P}_{\text {soil }}\right)$ of the 11 that varied mostly within each site (Table 5). 
Table 5. Results obtained from the regressions and partial regressions carried out for each of the first two principal components $\left(\mathrm{PC}_{\mathrm{i}}\right)$ of the Principal Component Analysis, and each soil and litter property. The table shows goodness of fit for all 19 models $\left(R^{2}\right)$, their $F$ values $(F)$, and their significances (p). The significance of each of the 19 models for incident solar radiation (SI) and the spatial filters (SF) are also shown. In addition, it shows the percent of relative contributions of incident solar radiation (R.SI), spatial structure (R.SF), and shared sunlight and spatial fraction (shrd) in explaining soil and litter variation on Marambaia Island. Ratios between the contributions of incident solar radiation and the spatial structure are also given (SI / SF)

\begin{tabular}{|c|c|c|c|c|c|c|c|c|c|}
\hline & $R_{a}^{2}$ & $\mathbf{F}$ & p & SI & SF & R.SI & R.SF & shrd & R.SI/R.SF \\
\hline PC 1 & 24.6 & 6.7 & 0.003 & 0.02 & 0.02 & 11.3 & 12.4 & 2.8 & $1 / 1.1$ \\
\hline PC 2 & 49.9 & 19.4 & $<.001$ & $<.001$ & 0.006 & 43.7 & 11.3 & 0.0 & $3.9 / 1$ \\
\hline $\mathrm{pH}_{\text {soil }}$ & 26.4 & 7.3 & 0.002 & 0.01 & 0.5 & 13.5 & 0.7 & 14.1 & $19.3 / 1$ \\
\hline $\mathrm{K}_{\text {soil }}$ & 42.4 & 14.4 & $<.001$ & $<.001$ & 0.01 & 23.2 & 10.6 & 10.1 & $2.2 / 1$ \\
\hline $\mathrm{Na}_{\text {soil }}$ & 22.6 & 6.0 & 0.005 & 0.05 & 0.004 & 8.3 & 18.7 & 0.0 & $1 / 2.2$ \\
\hline $\mathrm{P}_{\text {soil }}$ & 57.4 & 26.1 & $<.001$ & 0.01 & $<.001$ & 7.2 & 47.1 & 4.1 & $1 / 6.5$ \\
\hline $\mathrm{Ca}_{\text {soil }}$ & 13.6 & 3.5 & 0.04 & 0.3 & 0.02 & 2.5 & 14.3 & 0.0 & $1 / 5.7$ \\
\hline $\mathrm{Mg}_{\text {soil }}$ & 25.4 & 7.0 & 0.003 & 0.01 & 0.008 & 14.5 & 15.5 & 0.0 & $1 / 1.1$ \\
\hline $\mathrm{Al}_{\text {soil }}$ & 29.0 & 8.2 & 0.001 & 0.001 & 0.08 & 22.4 & 5.9 & 2.5 & $3.8 / 1$ \\
\hline $\mathrm{C}_{\text {soil }}$ & 13.7 & 3.5 & 0.04 & 0.04 & 0.17 & 10.1 & 4.4 & 1.4 & $2.3 / 1$ \\
\hline $\mathrm{N}_{\text {soil }}$ & 23.9 & 6.5 & 0.004 & 0.006 & 0.02 & 17.3 & 11.0 & 0.0 & $1.6 / 1$ \\
\hline $\mathrm{H}+\mathrm{Al}_{\text {soil }}$ & 20.9 & 5.5 & 0.008 & 0.02 & 0.12 & 12.3 & 5.4 & 5.2 & $2.3 / 1$ \\
\hline slt $_{\text {soil }}$ & 0.4 & 0.56 & 0.57 & 0.59 & 0.40 & 0.8 & 1.9 & 0.3 & $1 / 2$ \\
\hline snd $_{\text {soil }}$ & 32.5 & 9.6 & $<.001$ & 0.001 & 0.02 & 21.1 & 10.0 & 3.1 & $2.1 / 1$ \\
\hline $\mathrm{P}_{\text {litter }}$ & 20.3 & 5.3 & 0.009 & 0.009 & 0.16 & 16.1 & 4.4 & 1.8 & $3.7 / 1$ \\
\hline $\mathrm{K}_{\text {litter }}$ & 14.7 & 3.8 & 0.3 & 0.01 & 0.65 & 15.7 & 0.5 & 0.7 & 31.4 / 1 \\
\hline $\mathrm{N}_{\text {litter }}$ & 17.8 & 4.6 & 0.01 & 0.03 & 0.08 & 11.2 & 6.8 & 1.9 & $1.6 / 1$ \\
\hline $\mathrm{Ca}_{\text {litter }}$ & 27.1 & 7.5 & 0.002 & 0.01 & 0.02 & 14.0 & 12.2 & 2.8 & $1.1 / 1$ \\
\hline $\mathrm{Mg}_{\text {litter }}$ & 1.0 & 0.7 & 0.51 & 0.99 & 0.36 & 0.1 & 2.2 & 1.3 & $1 / 22$ \\
\hline
\end{tabular}

\section{DISCUSSION}

Our findings corroborate that topographic variation can have important effects on soil and litter variation patterns in tropical mountainous landscapes (Chen et al., 1997; Mulla and McBratney, 1999; Seibert et al., 2007; Sariyildiz and Küçük, 2008). Results indicate that slope geographic orientation is a main topographic feature driving soil and litter variation patterns in areas with heterogeneous terrain. However, most soil and litter variation was detected to occur within sites with slopes facing the same predominant geographic orientation. This suggests that topographic changes taking place on smaller scales than the overall scale considered here may have important effects on the soil and litter. Geographic orientation of slopes, surface curvature (concave, convex or plain), and altitude are all known to change within small distances in areas with heterogeneous topography (Sommer and Schlichting, 1997; Gao et al., 2011). Thus, it seems likely that thoroughly evaluating these topographic features on smaller scales (e.g., scales comparable to site A or site B alone) across areas such as mountain chains is likely to enhance our comprehension of soil and litter variability in tropical regions with heterogeneous topography.

Evidence in this study confirms that incident solar radiation can be a particularly important environmental factor in explaining soil and litter variation within the context of tropical heterogeneous landscapes. The detection of effects linking this factor to soil and litter variation further suggests that other environmental factors known to affect soil and litter may also be particularly relevant where topography features vary conspicuously (Fanning and Fanning, 1989; Dubayah, 1994; Gobin et al., 2001; Gao et al., 2011; Brady and Weil, 2013). This is supported by the fact that a considerable amount of variation in soil and litter properties remained unexplained after models were fitted. It is likely that direct effects of incident solar radiation on the soil and litter are hindered by the plant cover in tropical heterogeneous areas, allowing other environmental factors to act. Levels of light that reach the forest understory can be as low as $3 \%$ of the total incident solar radiation at the top of the canopy (Clark et al., 1996). Another reasonable hypothesis is that incident solar radiation has indirect effects on soil and litter, acting as a proxy 
for other environmental factors. Thus, incident solar radiation would primarily affect other environmental factors, which would then directly affect the soil and litter. Such reasoning is supported by efforts that relate soil and litter variation to changes in air and soil temperature, soil respiration, evapotranspiration, and litter decomposition rates in areas with heterogeneous topography (Borém and Ramos, 2002; Seibert et al., 2007; Sariyildiz and Küçük, 2008; Alvarez-Clare and Mack, 2011). Further evaluation of other environmental factors known to change with the terrain in heterogeneous areas together with the spatial structure of the area seems likely to increase our understanding of how environmental effects determine soil and litter variation in landscapes with complex topography.

A closer look at the contribution of incident solar radiation in explaining soil and litter variation between and within sites $\mathrm{A}$ and $\mathrm{B}$ under the perspective that it acts as a proxy for other environmental factors allows additional understanding of the patterns detected. Greater incident solar radiation on the slopes of site A would imply higher air temperature and humidity (provided that water is not limited and higher temperatures increase rates of evapotranspiration) which increase the local decomposition rate, resulting in higher values of $\mathrm{H}_{\text {soil }}$ and $\mathrm{N}_{\text {soil }}$. The inverse would be true for slopes of site B, causing the higher values of $\mathrm{K}_{\text {soil }}$ and $\mathrm{Mg}_{\text {soil }}$. Yet, there is also the possibility that greater $\mathrm{K}_{\text {soil }}$ and $\mathrm{Mg}_{\text {soil }}$ content on the slopes of site B may occur because this area faces open sea and is more likely to receive exchangeable bases carried by sea wind (Chadwick et al., 1999; Brady and Weil, 2013). However, we did not control for this source of variation and, thus, we encourage future efforts to consider position relative to the ocean as yet another relevant topographic feature affecting soil and litter variation at landscapes close to the sea. Additionally, an interesting pattern was that incident solar radiation also played an important role in the variation of most soil and litter properties within each site. This strengthens the suggestion that environmental changes may also arise on small scales due to topographic features (e.g., direction the slopes face, surface curvature, and altitude) changing within small distances in heterogeneous areas. The fact that slopes within each site had a predominant geographic orientation but had some variation regarding the direction they face supports this line of thought.

Finally, results here also show that soil and litter variation in tropical areas with heterogeneous topography should be expected to have a relevant spatial structure regardless of the environmental factors considered in the model. As previously implied, environmental factors are themselves spatially structured at such locations, due to changes in topographic features both on large and small scales (Silva et al., 2007). Results here corroborate that these terrain changes seem to determine not only environmental variation, but also the contagious distribution of soil and litter (Gobin et al., 2001; Sariyildiz and Küçük, 2008). It appears reasonable that heterogeneous topography increases the effects of spatially contagious mechanisms on the soil and litter due to a high number of paths, obstacles, and terrain shapes that direct material movement and water flow. Water is likely a key actor within the scope of soil and litter dynamics in tropical heterogeneous areas. Its solvent properties affect processes that determine the number of ions present in the soil and litter, and it may be expected to create gradients of fertility and sediment deposition when flowing over and through the landscape (Resende et al., 1995; Huggett, 2007). The occurrence of abundant rainfall and high air humidity in tropical regions further supports this reasoning.

\section{CONCLUSIONS}

Both soil and litter exhibited detectable variation patterns within and between slopes with distinct geographic orientation in tropical areas with heterogeneous topography.

Incident solar radiation played a relevant role in explaining soil and litter variation patterns within and between slopes with distinct geographic orientation in tropical areas with heterogeneous topography. Evidence further suggests that this factor may have indirect effects on the soil and litter and act as a proxy for other environmental factors with more direct effects.

The spatial structure of the area under study also played a relevant role in explaining soil and litter variation patterns and indicated that part of the patterns detected can be understood in light of smaller scale changes in topographic features.

\section{ACKNOWLEDGMENTS}

This study was completed as a result of the MSc candidacy of the lead author in the Graduate Studies Program in Ecology at the Universidade Federal do Rio de Janeiro. We thank the Centro de Avaliação da Ilha da Marambaia (CADIM) of the Brazilian Navy for allowing entrance to the area and for providing logistical support during field activities. We are very grateful to the Botanical Department and Soil Department of the Universidade Federal Rural do Rio de Janeiro for providing the structure for laboratory activities, and the numerous colleagues who helped in soil and litter sampling in the field. Lastly, we thank the anonymous referees for their valuable observations and suggestions, and CAPES for the grant provided to FC. 


\section{REFERENCES}

Aguilar C, Herrero J, Polo MJ. Topographic effects on solar radiation distribution in mountainous watersheds and their influence on reference evapotranspiration estimates at watershed scale. Hydrol Earth Syst Sci. 2010;14:2479-94.

Almeida FFM, Carneiro CR. Origem e evolução da Serra do Mar. R Bras Geoci. 1998;282:1-20.

Alvarez-Clare S, Mack MC. Influence of precipitation on soil and foliar nutrients across nine Costa Rican forests. Biotropica. 2011;43:433-41.

Aponte C, García LV, Marañón T. Tree species effects on nutrient cycling and soil biota: A feedback mechanism favoring species coexistence. For Ecol Manage. 2013;309:36-46.

Austin AT, Vivanco L. Plant litter decomposition in a semi-arid ecosystem controlled by photodegradation. Nature. 2006;442:555-8.

Borém RAT, Ramos DP. Variação estacional e topográfica de nutrientes na serapilheira de um fragmento de Mata Atlântica. Cerne. 2002;8:42-59.

Brady NC, Weil RR. Elementos da natureza e propriedades dos solos. $3^{\text {a }}$.ed. Porto Alegre: Bookman; 2013.

Brandt AJ, Kroon H, Reynolds HL, Burns JH. Soil heterogeneity generated by plant-soil feedbacks has implications for species recruitment and coexistence. J Ecol 2013;101:277-86.

Brummit N, Nic Lughadha E. Biodiversity. Where's hot and where's not. Conserv Biol. 2003;17:1442-8.

Budke JC, Jarenkow JA, Oliveira-Filho AT. Relationships between tree component structure, topography and soils of a riverside forest, Rio Botucaraí, Southern Brazil. Plant Ecol. 2007;189:187-200.

Chadwick OA, Derry LA, Vitousek PM, Hubert BJ, Hedin LO. Changing sources of nutrients during four million years of ecosystem development. Nature. 1999;397:491-7.

Chen Z, Hsieh C, Jiang F, Hsieh T, Sun I. Relations of soil properties to topography and vegetation in a subtropical rain forest in southern Taiwan. Plant Ecol. 1997;132:229-41.

Clark DB, Clark DA, Rich PM, Weis SE, Oberbauer SF. Landscape-scale evaluation of understory light and canopy structure: methods and application in a neotropical lowland rain forest. Can J For Res. 1996;26:747-57.

Dubayah RC. Modeling a solar radiation topoclimatology for the Rio Grande river watershed. J Veg Sci. 1994;5:627-40.

Empresa Brasileira de Pesquisa Agropecuária - Embrapa. Centro Nacional de Pesquisa do Solo. Manual de métodos de análise de solo. $2^{\text {a }}$.ed. Rio de Janeiro: 1997.

Fanning DS, Fanning MCB. Soil morphology, genesis, and classification. New York: John Wiley \& Sons; 1989.

Fassbender HW. Modelos edafológicos de sistemas agroflorestais. $2^{\mathrm{a}}$.ed. Turrialba, [Costa Rica]: Centro Agronómico Tropical de Investigación y Enseñanza; 1993.

Fortin MJ, Dale M. Spatial analysis: A guide for ecologists. Cambridge: Cambridge University Press; 2005.

Gao ZQ, Liu CS, Gao W, Chang NB. A coupled remote sensing and the Surface Energy Balance with Topography Algorithm (SEBTA) to estimate actual evapotranspiration over heterogeneous terrain. Hydrol Earth Syst Sci. 2011;15:119-39.
García LV, Maltez-Mouro S, Pérez-Ramos IM, Freitas H, Marañón T. Counteracting gradients of light and soil nutrients in the understorey of Mediterranean oak forests. Web Ecol. 2006;6:67-74.

Gleason SM, Read J, Ares A, Metcalfe DJ. Species-soil associations, disturbance, and nutrient cycling in an Australian tropical rainforest. Oecologia. 2010;162:1047-58.

Gobin A, Campling P, Feyen J. Soil-Landscape modelling to quantify spatial variability of soil texture. Phys Chem Earth. 2001;26:41-5.

Gotelli N, Ellison AM. A primer of ecological statistics. Sunderland [Massachusetts]: Sinauer Associates; 2004.

Homeier J, Breckle S-W, Günter S, Rollenbeck RT, Leuschner C. Tree diversity, forest structure and productivity along altitudinal and topographical gradients in a species-rich Ecuadorian montane rain forest. Biotropica. 2010;42:140-8.

Huggett RJ. Fundamentals of geomorphology. $2^{\mathrm{a}}$.ed. New York: Routledge; 2007.

Jenny H. Factors of soil formation: a system of quantitative. New York: McGraw-Hill; 1941.

John R, Dalling JW, Harms KE, Yavitt JB, Stallard RF, Mirabello M, Hubbell SP, Valencia R, Navarrete H, Vallejo M, Foster RB. Soil nutrients influence spatial distributions of tropical tree species. Proc Nat Acad Sci USA. 2007;104:864-9.

Laurance SGW, Laurance WF, Andrade A, Fearnside PM, Harms KE, Vicentini A, Luizão, RCC. Influence of soils and topography on Amazonian tree diversity: A landscape-scale study. J Veg Sci. 2010;21:96-106.

Leff JW, Nemergut DR, Grandy AS, Neill SPO, Wickings K, Townsend AR, Cleveland CC. The effects of soil bacterial community structure on decomposition in a tropical rain forest. Ecosystems. 2012;15:284-98.

Legendre P, Legendre L. Numerical ecology. $2^{\text {nd }}$.ed. Amsterdam: Elsevier Science BV; 1998.

Leigh EG, Davidar P, Dick CW, Puyravaud JP, Terborgh J, Ter Steege H, Wright SJ. Why do some tropical forests have so many species of trees? Biotropica. 2004;36:447-73.

Mattos CLV. Caracterização climática da restinga da Marambaia. In: Menezes LFT, Peixoto AL, Araujo DSD, editores. História natural da Marambaia. Seropédica: Edur; 2005. p.55-66.

Menezes LFT, Peixoto AL, Araujo DSD. História natural da Marambaia. Seropédica: Edur; 2005

Mulla DJ, Mcbratney AB. Soil spatial variability. In: Summer ME, editor. Handbook of science. New York: CRC Press; 1999. p.321-51.

Oksanen J, Blanchet FG, Kindt R, Legendre P, Minchin PR, O’Hara RB, Simpson GL, Solymos P, Stevens MHH, Wagner H. Vegan: Community ecology package. [Accessed: 2014 Aug.] Available at: http://CRAN.R-project.org/package=vegan

Oliveira Filho AT, Curi N, Vilela EA, Carvalho DA. Variation in tree community composition and structure with changes in soil properties within a fragment of semideciduous forest in south-eastern Brazil. Edinburgh J Bot. 2001;58:139-58.

Pereira LA, Xerez R, Pereira AMC. Ilha da Marambaia (Baía de Sepetiba, RJ): Resumo fisiográfico, histórico e importância ecológica atual. Ci Cult. 1990;42:384-9. 
Pinto JRR, Oliveira Filho AT, Hay JDV. Influence of soil and topography on the composition of a tree community in a central Brazilian valley forest. Edinburgh J Bot. 2006;62:69-90.

Putten WHVD, Bardgett RD, Bever JD, Bezemer TM, Casper BB, Fukami T, Kardol P, Klironomos JN, Kulmatiski A, Schweitzer JA, Suding KN, van de Voorde TFJ, Wardle DA. Plant-soil feedbacks: the past, the present and future challenges. J Ecol. 2013;101:265-76.

R Development Core Team. R: A language and environment for statistical computing. R Foundation for Statistical Computing. Vienna, [Austria]: 2014. [Accessed: 2014 Out.]. Available at: http://www.R-project.org.

Rangel TF, Diniz Filho JAF, Bini LM. SAM: A comprehensive application for spatial analysis in macroecology. Ecography. 2010;33:46-50.

Resende M, Curi N, Rezende SB, Corrêa GF. Pedologia: Base para distinção de ambientes. Viçosa, MG, [Br]: Núcleo de Estudo de Planejamento e Uso da Terra, 1995.

Sariyildiz T, Küçük M. Litter mass loss rates in deciduous and coniferous trees in Artvin, northeast Turkey: Relationships with litter quality, microclimate, and soil characteristics. Turk J Agric For. 2008;32:547-59.

Seibert J, Stendahl J, Sørensen R. Topographical influences on soil properties in boreal forests. Geoderma. 2007;141:139-48.

Silva DF. Ilha da Marambaia, RJ: Fatores externos, transformações econômicas e conflitos [dissertação]. Viçosa, MG [Br]: Universidade Federal de Viçosa; 2005.

Silva WG, Metzger JP, Simões S, Simonetti C. Relief influence on the spatial distribution of the Atlantic Forest cover on the Ibiúna Plateau, SP. Braz J Biol. 2007;67:403-11.
Sommer M, Schlichting E. Archetypes of catenas in respect to matter; a concept for structuring and grouping catenas. Geoderma. 1997;76:1-33.

Souza CRG, Suguio K, Oliveira AMS, Oliveira PE. Quaternário do Brasil. Ribeirão Preto: Holos; 2005.

Tedesco MJ, Gianello C, Bissani CA, Bohnen H, Volkweiss SJ. Análise de solos, plantas e outros materiais, $2^{\text {a }}$.ed. Porto Alegre: Universidade Federal do Rio Grande do Sul; 1995.

Troeh FR, Thompson LM. Soils and soil fertility. Oxford: Blackwell; 2005.

Unger M, Homeier J, Leuschner C. Effects of soil chemistry on tropical forest biomass and productivity at different elevations in the equatorial Andes. Oecologia. 2012;170:263-74.

Valeriano MM. Topodata - guia para utilização de dados geomorfométricos locais. 2008. [Accessed: July 2010]. Available at: http://www.dsr.inpe.br/topodata/documentos.php.

van de Berg E, Santos FAM. Aspectos da variação ambiental em uma floresta de galeria em Itutinga, MG, Brasil. Ci Flor. 2003;13:83-98.

Veloso HP, Folho ALRR, Lima JCA. Classificação da vegetação brasileira, adaptada a um sistema universal. Rio de Janeiro: IBGE/Departamento de Recursos Naturais e Estudos Ambientais; 1991.

Zuur AF, Ieno EN, Smith GM. Analysing ecological data. New York: Springer; 2007.

Zuur AF, Ieno EN, Walker NJ, Saveliev AA, Smith GM. Mixed effects models and extensions in ecology with R. New York: Springer; 2009. 